\title{
Kriteria Pemilihan Urutan Babi yang Disukai Konsumen di Kota Denpasar, Provinsi Bali
}

\author{
I Gusti Agung Teguh Gardipa, Nyoman Semadi Antara*, I Wayan Gede Sedana Yoga \\ PS Teknologi Industri Pertanian, Fakultas Teknologi Pertanian, Universitas Udayana, Kampus Bukit \\ Jimbaran, Badung, Kode pos : 80361; Telp/Fax : (0361) 701801.
}

Diterima 09 Agustus 2019 / Disetujui 15 Agustus 2019

\begin{abstract}
Bali has many traditional foods, the most popular traditional in Bali, sausage. This study aims to determine the criteria of the order of urutan product in the city of Denpasar, Bali and to find out the most priority characteristics among the criteria that have been determined against the order of urutan in the city of Denpasar, Bali. This study uses the AHP (Analytic Hierarchy Process) method. The results of this study indicate that the AHP Test on the criteria shows that the weighting of the five experts is included in the criteria consistently and it can be concluded that the most important criterion is the taste criteria, with score of 0.350. The most important criteria in the sub-criteria for taste are the spicy subcriteria, with score of 0.505 . The most important criterion in the sub-criteria in the process is the sun criteria sub-criteria, with a score of 0.329. The most important criteria in the sub-criteria for the composition are the fat meat sub-criteria, with a score of 0.622. The most important criteria in the subcriteria at the price are the 80-90 sub-criteria with a score of 0.478. The most important criterion in the sub-criteria for texture is the soft sub-criteria which is a score of 0.758 .
\end{abstract}

Keywords: Urutan, AHP, fermentted sausage

*Korespondensi Penulis:

Email : semadi.antara@unud.ac.id 


\section{PENDAHULUAN}

\section{Latar Belakang}

Pulau Bali disamping terkenal karena alam dan budayanya juga terkenal dengan beranekaragam makanan tradisional yang tidak dapat ditemui di daerah lain (Shanti. 2013). Beragam makanan tradisional tersebut, salah satunya adalah urutan atau sosis dengan menggunakan daging babi. ( Suter, 1999)

Urutan di Bali dibuat dari daging babi yang dipotong kecil-kecil kemudian ditambahkan garam dan campuran bumbu (bawang putih, kunyit, kencur, cabai, lengkuas, merica, garam, dan gula) setelah itu dimasukkan ke dalam selongsong usus babi (Lawrie, 1995). Cara penyajian adalah digoreng, namun apabila diinginkan proses fermentasi daging yang telah dimasukkan ke dalam selongsong tersebut difermentasi selama 2 - 4 hari dibawah sinar matahari (Susanto, 2012). Suhu fermentasi berfluktuasi antara $50^{\circ} \mathrm{C}$ pada siang hari dan $25^{\circ} \mathrm{C}$ pada malam hari (Antara dkk., 2004). Resiko kegagalan saat fermentasi sangat tinggi karena mudahnya terkontaminasi mikroba perusak makanan (Hechelmann , 1986).

Di pasar tradisional maupun di warungwarung khususnya diseputaran Denpasar banyak terdapat makanan tradisional seperti urutan dengan berbagai macam rasa, ukuran, harga, proses pengolaham, penyajiannya dan berbagai macam kriterianya, Oleh karena itu perlu dilakukan penelitian lebih dalam mengenai kriteria terhadap produk tersebut. Upaya antisipasi dan penanggulangan persoalan diatas, untuk mengambil keputusan maka digunakan metode AHP (Analytical Hierarchy Process). Berdasarkan latar belakang di atas, maka permasalahan yang akan dibahas dalam penelitian ini yaitu, kriteria apa saja yang ada dalam urutan babi di kota Denpasar, Bali ?, Berdasarkan kriteria yang sudah ditentukan, kriteria apa saja yang paling prioritas terhadap urutan babi dikota Denpasar, Bali ?

Tujuan dari penelitian ini adalah, menentukan kriteria urutan babi di kota Denpasar, Bali. Untuk mengetahui Kriteria yang paling prioritasi di kota Denpasar, Bali. Hasil penelitian ini diharapkan dapat memberikan informasi secara ilmiah kepada masyrakat mengenai produk urutan babi yang diproduksi di kota Denpasar.

\section{METODE PENELITIAN}

\section{Tempat dan Waktu Penelitian}

Penelitian ini dilakukan selama 6 bulan, yaitu dari bulan Maret 2018 sampai September 2018. Pelaksanaan penelitian ini dilakukan di pasar tradisional seputaran kota Denpasar Provinsi Bali.

\section{Tahapan Proses Penelitian}

Penelitian yang dilakukan adalah jenis penelitian survey. Tahapan proses penelitian terdiri dari survey pendahuluan, perumusan masalah dan tujuan penelitiaan, studi pustaka, identifikasi variabel penelitian, penyusunan kuisioner, pengumpulan data dan analisis data.

Menurut Saaty (2001), tahapan tahapan pengambilan keputusan dalam metode AHP pada dasarnya adalah sebagai berikut :

a. Medefinisikan masalah dan menentukan solusi yang diinginkan.

b. Membuat struktur hirarki yang diawali dengan tujuan umum (goal), dilanjutkan dengan kriteria - kriteria dan alternatif alternatif pilihan yang ingin dirangking

c. Membentuk matriks perbandingan berpasangan yang menggambarkan kontribusi relative atau pengaruh setia elemen terhadap masing - masing tujuan atau kriteria yang setingkat diatas. Perbandingan dilakukan berdasarkan pilihan dari pembuat keputusan dengan menilai tingkat - tingkat kepentingann 
suatu elemen dibandingkan dengan elemen lainnya.

d. Menormalkan data yaitu dengan membagi nilai dari setiap elemen didalam matriks yang berpasangan dengan nilai total dari setiap kolom.

e. Menghitung nilai eigen vector dan menguji konsistensinya, jika tidak konsisten maka pengambilan data perlu diulang. Nilai eigen vector yang dimaksud adalah nilai eigen vector maksimum yang diperoleh dengan menggunakan mathlab atau manual.

f. Mengulang langkah c, d, dan e untuk seluruh hirarki.

g. Menghitung eigen vector dari setiap matriks perbandingan berpasangan. Nilai eigen vector merupakan bobot setiap elemen. Langkah ini untuk mensintesis pilihan dalam penentuan prioritas elemen pada tingkat hirarki terendah sampai pencapaian tujuan.

h. Menguji konsistensi hirarki. Jika tidak ada memenuhi dengan $\mathrm{CR} \leq 0,100$ maka penilaian harus diulang kembali.

Prioritas pemilihan dilakukan oleh lima pakar yang berpengalaman dan mempunyai pengetahuan mengenai urutan. lima pakar tersebut terdiri dari 1 pakar akademisi 2 pakar produsen urutan dan 2 pelaku konsumen urutan babi atau pelaku bisnis.

Pemilihan pakar didasarkan atas pertimbangan dan kriteria - kriteria berikut (Marimin, 2004):

1. Mendapatkan pengakuan secara objektif terhadap kemampuan professional yang dimiliki oleh lingkungan akademik dan masyarakat luas.

2. Mempunyai produktivitas yang tinggi dalam bidang ilmiah yang ditekuni

3. Mempunyai reputasi kedudukan dan menunjukan kredibilitas sebagai ahli

4. Berpengalaman dibidang minimal 5 tahun.

5. Berasal dari praktisi dalam bidang urutan Babi.

Klasifikasi pakar ini lebih didasarkan pada lama kerja dan wewenang (terdidik secar formal atau otodidak) disuatu posisi kegiatan teknik tertentu.

Pada penelitian ini menggunakan pendapat dari pakar yang memiliki kompetensi tinggi terhadap masalah yang diselesaikan (Rani, 2018). Untuk memilih kriteria tersebut diperlukan kriteria tertentu. Kriteria tersebut di sajikan pada gambar 1.

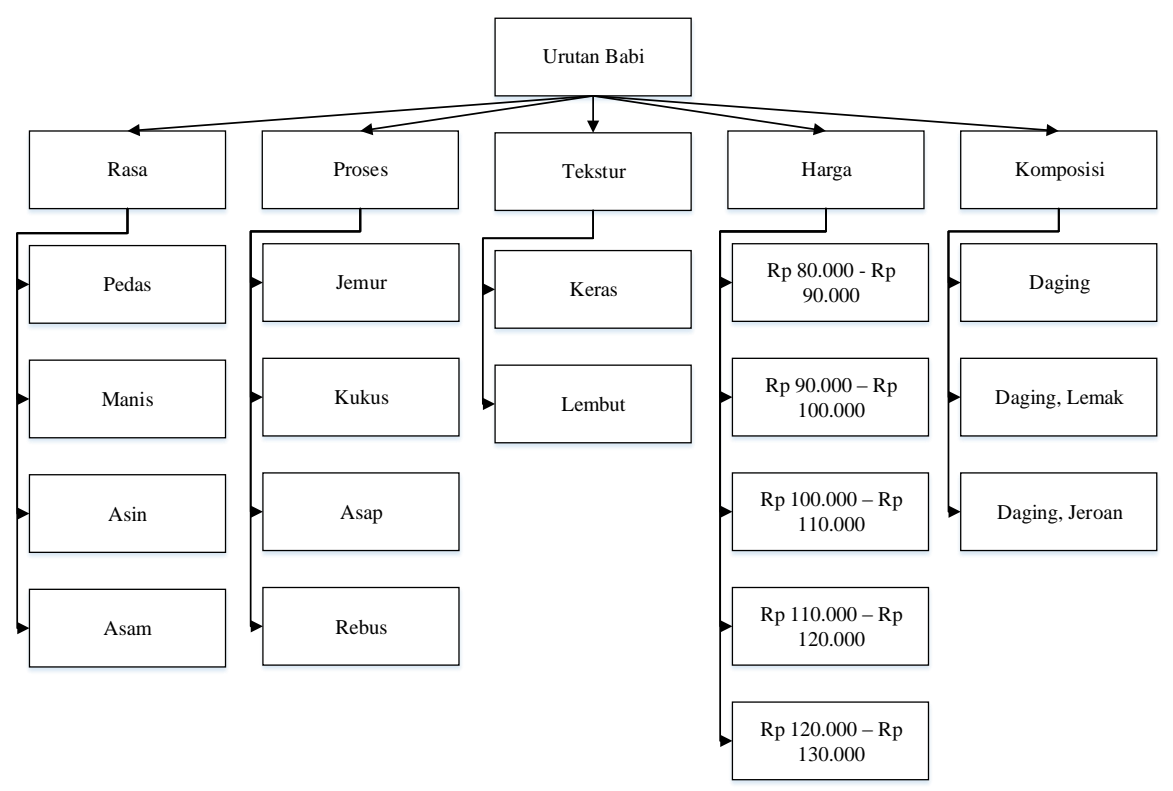

Gambar 1. Diagram AHP Urutan Babi. 
Tabel 1. Tabel Kriteria dan Sub Kriteria.

\begin{tabular}{|l|l|l|}
\hline NO & KRITERIA & SUB KRITERIA \\
\hline 1 & Rasa & Pedas \\
& & Manis \\
& & Asin \\
& & Asam \\
\hline 2 & Harga & Rp.80.000-Rp. 90.000 \\
& & Rp. 90.000-Rp. 100.000 \\
& & Rp. $100.000-$ Rp. 110.000 \\
& & Rp.110.000-Rp.120.000 \\
& & Rp.120.000-Rp.130.000 \\
\hline 3 & Tekstur & Keras \\
& & Lembut \\
\hline 4 & Proses & Jemur \\
& & Kukus \\
& & Asap \\
\hline 5 & Komposisi & Rebus \\
\hline & & Daging \\
& & Daging, lemak \\
\hline
\end{tabular}

Kriteria dan sub kriteria diatas adalah hasil diskusi dengan lima orang pakar, diperoleh 5 kriteria dengan sub kriterianya masing-masing. Kriteria dan sub kriteria dipilih oleh pakar dengan menggunakan metode Focus Groub Discussion (FGD).

\section{HASIL DAN PEMBAHASAN}

\section{Kriteria Urutan Babi}

Berdasarkan data pembobotan kriteria yang diperoleh dari hasil penyebaran kuisoner kepada lima orang pakar kemudian dilakukan perhitungan dengan menggunakan metode AHP diperoleh hasil uji AHP dapat dilihat pada tabel 2. Uji AHP pada kriteria menunjukan bahwa pembobotan pada kelima pakar termasuk dalam kriteria konsisten dan dapat disimpulkan bahwa kriteria terpenting adalah kriteria rasa yaitu dengan skor 0,400 kemudian kriteria kedua adalah proses dengan skor 0,231. Kriteria ketiga adalah komposisi dengan skor 0,181 , kriteria ke empat adalah tekstur dengan skor 0,105. dan kriteria kelima adalah harga dengan skor
0,082. Menurut pakar, kriteria rasa menjadi kriteria terpenting karena konsumen cenderung lebih memilih urutan yang memiliki rasa yang baik. Kriteria kriteria yang lain seperti proses dan komposisi menjadi kesan terhadap penunjang rasa pada urutan yang akan menjadi nilai tambah atau meningkatkan ketertarikan terhadap urutan tersebut. Menurut pakar harga dan tekstur memiliki nilai yang lebih rendah karena konsumen lebih mementingkan tiga kriteria diatas dibandingkan dengan harga dan tekstur.

\section{Kriteria Terpenting}

Berdasarkan data pembobotan sub kriteria pada rasa yang diperoleh dari hasil penyebaran kuisoner kepada lima orang pakar kemudian dilakukan perhitungan dengan menggunakan metode AHP diperoleh hasil uji AHP dapat dilihat pada tabel 3.

Uji AHP sub kriteria pada rasa menunjukan bahwa pembobotan pada kelima pakar termasuk dalam kriteria konsisten dan dapat disimpulkan bahwa kriteria terpenting 
dalam sub kriteria pada rasa adalah sub kriteria pedas yaitu dengan skor 0,527. kemudian sub kriteria kedua adalah manis dengan skor 0,310. Sub kriteria ketiga adalah asam dengan skor 0,087, sub kriteria ke empat adalah asin dengan skor 0,076.

Tabel 2. Hasil uji AHP pada kriteria terpenting.

\begin{tabular}{|l|c|c|c|c|c|c|c|}
\hline \multicolumn{1}{|c|}{ Kriteria } & Pakar 1 & Pakar 2 & Pakar 3 & Pakar 4 & Pakar 5 & Total & Rerata \\
\hline Rasa & 0,468 & 0,165 & 0,449 & 0,473 & 0,448 & 2,002 & 0,400 \\
\hline Proses & 0,268 & 0,279 & 0,169 & 0,241 & 0,198 & 1,155 & 0,231 \\
\hline Komposisi & 0,091 & 0,365 & 0,194 & 0,096 & 0,160 & 0,906 & 0,181 \\
\hline Tekstur & 0,084 & 0,124 & 0,109 & 0,047 & 0,163 & 0,527 & 0,105 \\
\hline Harga & 0,089 & 0,068 & 0,079 & 0,143 & 0,031 & 0,410 & 0,082 \\
\hline CR & 0,099 & 0,099 & 0,078 & 0,081 & 0,094 & \multicolumn{2}{|l}{} \\
\cline { 1 - 5 }
\end{tabular}

Menurut pakar, sub kriteria pedas menjadi sub kriteria terpenting pada kriteria rasa karena konsumen cenderung lebih memilih Urutan yang memiliki rasa yang pedas. Sub kriteria yang lain seperti manis, menjadi kesan terhadap penunjang rasa pada Urutan yang akan menjadi nilai tambah atau meningkatkan ketertarikan terhadap urutan tersebut. Menurut pakar asin dan asam memiliki nilai yang lebih rendah karena konsumen lebih mementingkan dua sub kriteria diatas dibandingkan dengan asin dan asam. Menurut (Markindo, 2019) rasa sosis yang berkualitas akan terasa daging yang kuat, beserta aneka bumbu yang dipakai, dan tidak getir di mulut.

Tabel 3. Hasil uji AHP sub kriteria pada rasa.

\begin{tabular}{|l|c|c|c|c|c|c|c|}
\hline \multicolumn{7}{|c|}{ RASA } \\
\hline & Pakar 1 & Pakar 2 & Pakar 3 & Pakar 4 & Pakar 5 & Total & Rerata \\
\hline Pedas & 0,450 & 0,525 & 0,606 & 0,450 & 0,606 & 2,637 & 0,527 \\
\hline Manis & 0,417 & 0,342 & 0,262 & 0,417 & 0,113 & 1,550 & 0,310 \\
\hline Asam & 0,067 & 0,067 & 0,066 & 0,066 & 0,167 & 0,433 & 0,087 \\
\hline Asin & 0,067 & 0,067 & 0,065 & 0,067 & 0,113 & 0,379 & 0,076 \\
\hline CR & 0,001 & 0,075 & 0,092 & 0,001 & 0,092 & & \\
\hline
\end{tabular}

Berdasarkan data pembobotan sub kriteria pada proses yang diperoleh dari hasil penyebaran kuisoner kepada lima orang pakar kemudian dilakukan perhitungan dengan menggunakan metode AHP diperoleh hasil uji AHP dapat dilihat pada tabel 4.

Uji AHP sub kriteria pada proses menunjukan bahwa pembobotan pada kelima pakar termasuk dalam kriteria konsisten dan dapat disimpulkan bahwa kriteria terpenting dalam sub kriteria pada proses adalah sub kriteria jemur yaitu dengan skor 0,555 kemudian sub kriteria kedua adalah kukus dengan skor 0,194. Sub kriteria ketiga adalah asap dengan skor 0,155 , sub kriteria ke empat adalah rebus dengan skor 0,097. Menurut pakar, sub kriteria jemur menjadi sub kriteria terpenting pada kriteria proses karena konsumen cenderung lebih memilih Urutan yang menggunakan proses jemur karena proser jemur atau fermentasi membuat bumbu pada urutan lebih terasa. Sub kriteria yang lain seperti asap, menjadi kesan terhadap penunjang proses pembuatan pada Urutan yang akan menjadi nilai tambah atau meningkatkan ketertarikan terhadap urutan 
tersebut. Menurut pakar kukus dan rebus memiliki nilai yang lebih rendah karena konsumen lebih mementingkan dua sub kriteria diatas dibandingkan dengan sub kriteria kukus dan rebus.

Tabel 4. Hasil uji AHP sub kriteria pada Proses.

\begin{tabular}{|c|c|c|c|c|c|c|c|}
\hline \multicolumn{8}{|c|}{ PROSES } \\
\hline & Pakar 1 & Pakar 2 & Pakar 3 & Pakar 4 & Pakar 5 & Total & Rerata \\
\hline Jemur & 0,607 & 0,438 & 0,593 & 0,608 & 0,526 & 2,773 & 0,555 \\
\hline Kukus & 0,082 & 0,325 & 0,192 & 0,223 & 0,147 & 0,968 & 0,194 \\
\hline Asap & 0,255 & 0,099 & 0,089 & 0,063 & 0,267 & 0,773 & 0,155 \\
\hline Rebus & 0,056 & 0,139 & 0,126 & 0,106 & 0,061 & 0,487 & 0,097 \\
\hline $\mathrm{CR}$ & 0,066 & 0,056 & 0,095 & 0,086 & 0,093 & & \\
\hline
\end{tabular}

Berdasarkan data pembobotan sub kriteria pada komposisi yang diperoleh dari hasil penyebaran kuisoner kepada lima orang pakar kemudian dilakukan perhitungan dengan menggunakan metode AHP diperoleh hasil uji AHP dapat dilihat pada tabel 5.

Tabel 5. Hasil uji AHP sub kriteria pada komposisi.

\begin{tabular}{|c|c|c|c|c|c|c|c|}
\hline \multicolumn{8}{|c|}{ KOMPOSISI } \\
\hline & Pakar 1 & Pakar 2 & Pakar 3 & Pakar 4 & Pakar 5 & Total & Rerata \\
\hline Daging Lemak & 0.458 & 0.671 & 0.723 & 0.458 & 0.800 & 3.110 & 0.622 \\
\hline Daging & 0.479 & 0.244 & 0.187 & 0.479 & 0.100 & 1.489 & 0.298 \\
\hline Daging Jeroan & 0.062 & 0.085 & 0.090 & 0.063 & 0.100 & 0.400 & 0.080 \\
\hline $\mathrm{CR}$ & 0,002 & 0,095 & 0,047 & 0,002 & 0,000 & & \\
\hline
\end{tabular}

Uji AHP sub kriteria pada komposisi menunjukan bahwa pembobotan pada kelima pakar termasuk dalam kriteria konsisten dan dapat disimpulkan bahwa kriteria terpenting dalam sub kriteria pada komposisi adalah sub kriteria daging lemak yaitu dengan skor 0,622 kemudian sub kriteria kedua adalah daging dengan skor 0,298. Sub kriteria ketiga adalah daging jeroan dengan skor 0,080. Menurut pakar, sub kriteria daging lemak menjadi sub kriteria terpenting pada kriteria komposisi karena konsumen cenderung lebih memilih Urutan dengan komposisi daging lemak. Sub kriteria yang lain seperti daging, menjadi kesan terhadap penunjang komposisi pada Urutan yang akan menjadi nilai tambah atau meningkatkan ketertarikan terhadap urutan tersebut. Menurut pakar daging jeroan memiliki nilai yang lebih rendah karena konsumen lebih mementingkan dua sub kriteria diatas dibandingkan dengan sub kriteria daging jeroan.

Berdasarkan data pembobotan sub kriteria pada harga yang diperoleh dari hasil penyebaran kuisoner kepada lima orang pakar kemudian dilakukan perhitungan dengan menggunakan metode AHP diperoleh hasil uji AHP dapat dilihat pada tabel 6 . 
Tabel 6. Hasil uji AHP sub kriteria pada harga.

\begin{tabular}{|c|c|c|c|c|c|c|c|}
\hline \multicolumn{8}{|c|}{ HARGA } \\
\hline (Dalam ribu rupiah) & Pakar 1 & Pakar 2 & Pakar 3 & Pakar 4 & Pakar 5 & Total & Rerata \\
\hline $80-90$ & 0,484 & 0,459 & 0,493 & 0,470 & 0,560 & 2,466 & 0,493 \\
\hline $90-100$ & 0,265 & 0,302 & 0,263 & 0,295 & 0,229 & 1,354 & 0,271 \\
\hline $100-110$ & 0,137 & 0,127 & 0,125 & 0,129 & 0,119 & 0,637 & 0,127 \\
\hline $110-120$ & 0,076 & 0,073 & 0,079 & 0,061 & 0,053 & 0,342 & 0,068 \\
\hline $120-130$ & 0,038 & 0,039 & 0,039 & 0,046 & 0,039 & 0,201 & 0,040 \\
\hline $\mathrm{CR}$ & 0,098 & 0,091 & 0,096 & 0,086 & 0,101 & & \\
\hline
\end{tabular}

Uji AHP sub kriteria pada harga menunjukan bahwa pembobotan pada kelima pakar termasuk dalam kriteria konsisten dan dapat disimpulkan bahwa sub kriteria terpenting pada harga yaitu sub kriteria Rp. 80.000 - Rp.90.000 dengan skor 0,493 kemudian sub kriteria kedua adalah Rp. 90.000 - Rp.100.000 dengan skor 0,271. Sub kriteria ketiga adalah Rp. 100.000 Rp.110.000 dengan skor 0,127, sub kriteria ke empat adalah Rp.110.000 - Rp.120.000 dengan skor 0,068 dan sub kriteria kelima adalah Rp.120.000 - Rp.130.000 dengan skor 0,040. Menurut pakar, sub kriteria Rp.80.000 - Rp.90.000 menjadi sub kriteria terpenting karena konsumen cenderung lebih memilih Urutan yang memiliki harga Rp.80.000 - Rp. $90.000 \mathrm{rb} / \mathrm{kg}$. sub kriteria yang lain seperti Rp.90.000 - Rp.100.000 dan Rp.100.000 Rp.110.000 menjadi kesan terhadap penunjang harga pada Urutan. Menurut pakar Rp.110.000 - Rp.120.000 dan Rp.120.000Rp.130.000 memiliki nilai yang lebih rendah karena konsumen lebih mementingkan tiga sub kriteria diatas dibandingkan dengan Rp.110.000 - Rp.120.000 dan Rp.120.000Rp.130.000. Menurut (Markindo, 2019) harga jual sosis alami tentu lebih mahal. Umumnya, sosis alami dipatok dengan harga lebih dari Rp 100.000 per kilogram.

Tabel 7. Hasil uji AHP sub kriteria pada tekstur.

\begin{tabular}{|l|c|c|c|c|c|c|c|}
\hline \multicolumn{2}{|c|}{ TEKSTUR } \\
& Pakar 1 & Pakar 2 & Pakar 3 & Pakar 4 & Pakar 5 & Total & Rerata \\
\hline Lembut & 0.875 & 0.667 & 0.875 & 0.875 & 0.500 & 3.792 & 0.758 \\
\hline Keras & 0.125 & 0.333 & 0.125 & 0.125 & 0.500 & 1.208 & 0.242 \\
\hline CR & 0,000 & 0,000 & 0,000 & 0,000 & 0,000 & \multicolumn{1}{c}{} \\
\cline { 1 - 5 } &
\end{tabular}

Berdasarkan data pembobotan sub kriteria pada tekstur yang diperoleh dari hasil penyebaran kuisioner kepada lima orang pakar kemudian dilakukan perhitungan dengan menggunakan metode AHP diperoleh hasil uji AHP dapat dilihat pada tabel 7.

Uji AHP sub kriteria pada tekstur menunjukan bahwa pembobotan pada kelima pakar termasuk dalam kriteria konsisten dan dapat disimpulkan bahwa kriteria terpenting dalam sub kriteria pada tekstur adalah sub kriteria lembut yaitu dengan skor 0,758 kemudian sub kriteria kedua adalah keras dengan skor 0,242. Menurut pakar, sub kriteria lembut menjadi sub kriteria terpenting pada kriteria tekstur karena konsumen cenderung lebih memilih Urutan dengan tekstur yang lembut. Sub kriteria yang lain seperti keras, memiliki nilai yang lebih rendah karena konsumen lebih 
mementingkan sub kriteria lembut. Menurut (Markindo, 2019) dengan bahan olahan daging sapi, Sosis berbahan alami memiliki kekenyalan yang sedang. Tidak terlalu kenyal atau keras, tapi juga tidak terlalu empuk. Saat sosis dipotong, akan terlihat permukaan berpori yang berasal dari tekstur daging yang dihaluskan.

Secara keseluruhan hasil dari penilaian pakar tentang Presepsi Konsumen Terhadap Urutan Babi dengan menggunakan metode
Analytical Hierarchy Process (AHP) di kota Denpasar, Provinsi Bali, secara berturut-turut yaitu: urutan yang direkomendasikan untuk diproduksi oleh produsen adalah urutan babi dengan rasa pedas $(0,505)$, jemur $(0,329)$, komposisi daging lemak $(0,622)$, harga berkisar antara Rp 80.000 sampai dengan Rp 90.000 (0,478), serta tekstur yang lembut $(0,758)$. Hasil lengkap penilaian konsumen dapat dilihat pada gambar 2 .

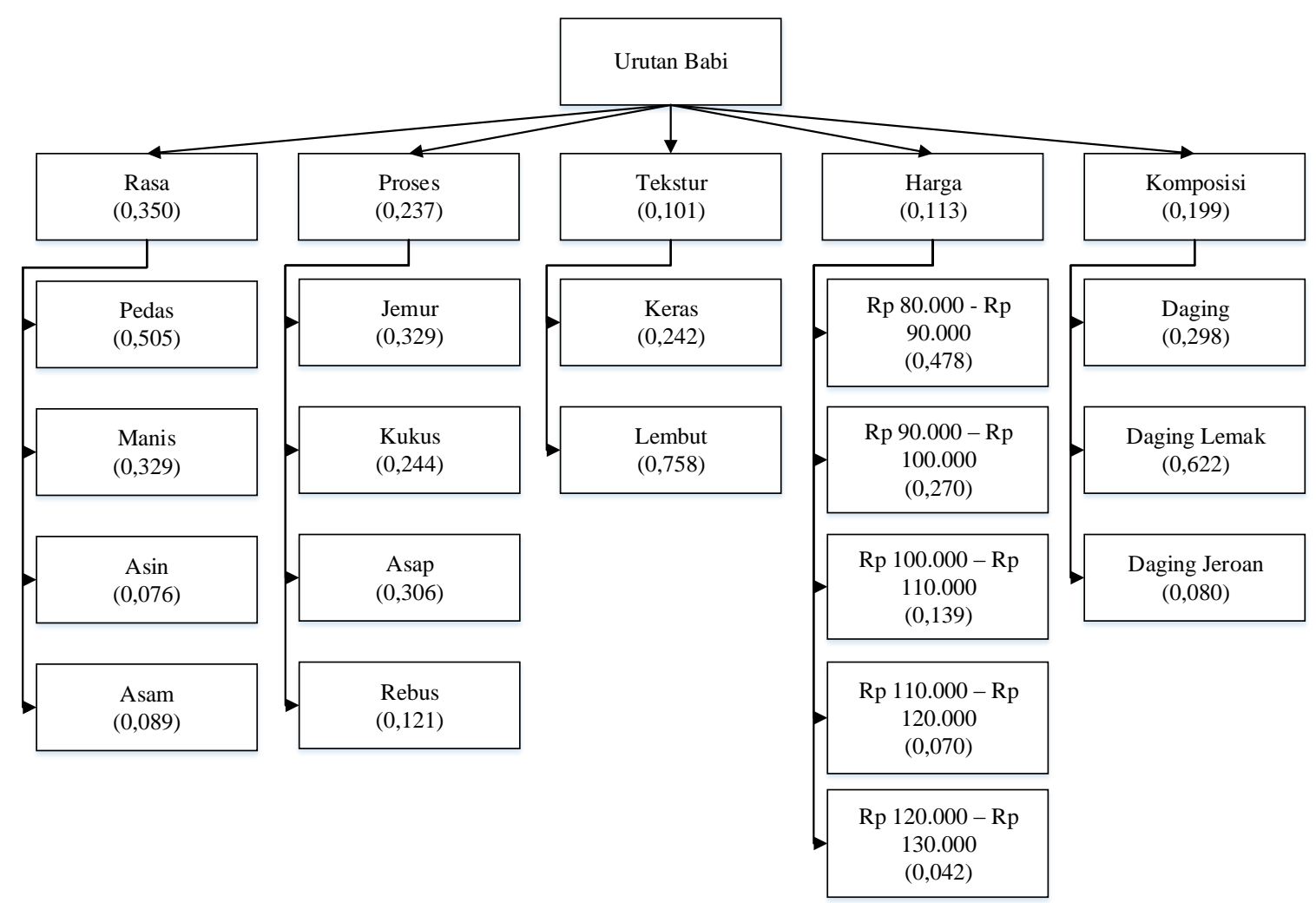

Gambar 2. Diagram Hasil AHP Urutan Babi.

\section{KESIMPULAN DAN SARAN}

\section{Kesimpulan}

Menurut pakar, persepsi konsumen terhadap urutan babi di kota Denpasar menunjukan kriteria dari yang terpenting: (1) kriteria Rasa $(0,400)$ dengan sub kriteria Pedas $(0,527)$, (2) Proses $(0,231)$ yaitu sub kriteria Dijemur $(0,555)$; (3) kriteria Komposisi $(0,181)$ adalah sub kriteria Daging Lemak (0,622); kriteria Tekstur $(0,105)$ dengan sub kriteria lembut $(0,758)$; (5) dan kriteria Harga $(0,082)$ dengan sub kriteria Rp.80,000-90.000 (0,493).

\section{Saran}

Berdasarkan hasil penelitian, menurut pakar produsen sebaiknya memproduksi urutan dengan rasa pedas, menggunakan proses dijemur dengan komposisi daging lemak, dan tekstur yang lembut, dengan kisaran harga jual Rp 80.000 - Rp 90.000/kg. 


\section{DAFTAR PUSTAKA}

Antara, N.S., Sujaya, I N., Yokota, A., Asano, K., Aryanta, W.R. and Tomita, F. 2004. Effects of indigenous starter culture on the microbial and physicochemical characteristic of urutan, a Balinese fermented sausage. J. Biosci. Bioeng. 98(2): 92-98.

Hechelmann, H. 1986. Mikrobiell Verursachte Fehlfabrikate bei Rohwurst und Rohschinken. Fleischwirthschaaft 66.

Lawrie, R. A., 1995. Ilmu Daging. Edisi kelima. Diterjemahkan oleh Parakkasi, A. UI-Press. Jakarta.

Markindo. 2019. Mengenal Lebih Dekat Sosis Sapi Yang Disukai. http://www.markaindo.co.id/id/publika si/mengenal-lebih-dekat-sosis-sapiyang-banyak-disukai/. Diakses pada tanggal 21- 05- 2019.

Marimin. 2004. Teknik dan Aplikasi Pengambilan Keputusan Kriteria Majemuk. PT Gramedia Widiasarana Indonesia. Jakarta.
Pujaastawa, I. B. G. 2003. "Pariwisata Subak : Menjaga Identitas Budaya dan Keseimbangan Ekologi Bali Tengah", dalam Guratan Budaya Universitas.

Susanto, E., M. Dahlan, D. W. Aspriati. 2012. Identifikasi Daging Babi dalam Sosis melalui Karakterisasi Protein Myofibril. Laporan Hasil Skim Penelitian Dosen Pemula. DiktiKemendiknas. Jakarta.

Suter, I K., I W. Arga, I N. K. Putra, N.S. Antara, A.A.M.S. Jelantik, M. Hartawan, dan I K. Satriawan. 1999. Inventarisasi 60 Jenis Makanan dan Minuman Daerah. Laporan Penelitian. Pusat Kajian Makanan Tradisional Madya. Universitas Udayana. Bukit Jimbaran.

Shanti. 2013. Urutan, Sosis Tradisional Masyarakat Bali. Available: http://santhiserad.com/2013/06/uruta n-sosis-tradisional-masyarakat-bali. [29 Juni 2013]. 